\title{
Lithium chloride inhibits the expression and secretion of insulin-like growth factor-binding protein-1
}

\author{
M S Lewitt, K Brismar, J Ohlson and J Hartman \\ Department of Molecular Medicine, Karolinska Institutet, Stockholm S-171 76, Stockholm \\ (Requests for offprints should be addressed to M Lewitt; Email: moira.lewitt@molmed.ki.se) \\ J Ohlson and J Hartman contributed equally to this work
}

\begin{abstract}
Insulin-like growth factor-binding protein-1 (IGFBP-1) regulates IGF availability for glucose homeostasis. The IGFBP-1 promoter shares common regulatory response elements with phosphoenolpyruvate carboxykinase (PEPCK), the expression and activity of which is inhibited by lithium chloride, associated with an inhibition of glycogen synthase kinase (GSK)-3 activity, in the rat hepatoma cell line H4-II-E. We therefore determined the effect of lithium chloride on IGFBP-1 expression and secretion in H4-II-E cells. Lithium chloride inhibited IGFBP-1 secretion in a dose response and reversible manner by approx $80 \%$ during $5-\mathrm{h}$ and $16-\mathrm{h}$ incubations.
\end{abstract}

An inhibitory effect on IGFBP-1 mRNA expression was observed at $2 \mathrm{~h}$. The inhibitory effect of lithium and insulin were not additive when used alone, but inhibition by lithium occurred when insulin action was blocked by activating AMP-activated protein kinase with 5-aminoimidazole-4-carboxamide-riboside (AICAR). These findings suggest that GSK-3 inhibition, or another pathway activated by lithium, may be involved in a pathway controlling IGFBP-1, inhibiting synthesis when insulin activity is absent or impaired.

Journal of Endocrinology (2001) 171, R11-R15

\section{Introduction}

The insulin-like growth factor-binding proteins (IGFBPs) are a family of six peptides which have high affinity IGF binding but also IGF-independent activities (Baxter, 2000). IGFBP-1 is characterised by dynamic variability of levels in the circulation due to regulation of its hepatic secretion (Lee et al., 1997). Insulin is a dominant inhibitor of hepatic IGFBP-1 transcription under normal physiological conditions. This inverse relationship allows endocrine IGFBP-1 to act as a glucose counterregulator, blocking availability of IGFs for glucose homeostasis. During conditions such as catabolic stress (Cotterill et al., 1996) and intensive exercise (Hopkins et al., 1994) the inverse correlation between insulin and IGFBP-1 may be lost. Hepatic insulin resistance and circulating stimulators of IGFBP-1 may have direct roles, and these factors may interact. Insulin is unable to attenuate interleukin 6-stimulated IGFBP-1 secretion in HepG2 human hepatoma cells (Samstien et al., 1996). The AMP-activated protein kinase (AMPK) pathway is activated by environmental stresses such as hypoxia and intensive exercise. We have recently shown that an AMPK activator may also block the inhibitory effect of insulin on IGFBP-1 (Lewitt, 2001). Insulin inhibits IGFBP-1 via phosphatidylinositol 3-kinase (PI3K) and protein kinase B (PKB/Akt) (Cichy et al., 1998) by inhibiting activation by the Forkhead transcription factor, FKHR (Kops et al., 1999). An inhibitory effect of AMPK activation on insulin-induced glucose uptake is mediated downstream of PI3K in 3T3-L1 adipocytes (Salt et al., 2000).

IGFBP-1 and PEPCK promoters share common regulatory response elements, however their patterns of regulation may differ. In H4-II-E cells, for example, AMPK activation stimulates IGFBP-1 (Lewitt, 2001), but inhibits PEPCK (Lochhead et al., 2000). It has been reported that lithium chloride inhibits PEPCK gene expression (Bosch et al., 1992). Lithium is a potent allosteric inhibitor of glycogen synthase kinase-3 (GSK-3) (Davies et al., 2000). It is also reported to activate $\mathrm{PKB} / \mathrm{Akt}$ (Chalecka-Franaszek \& Chuang, 1999) and, in high concentrations, to inhibit casein kinase 2 (Davies et al., 2000). In H4-II-E cells the action of lithium on PEPCK expression mimics that of selective inhibitors of GSK-3 and is independent of PKB/Akt and FKHR (Lochhead et al., 2001).

The aim of these studies was to determine the effect of lithium in H4-II-E cells on IGFBP-1 secretion and expression in the presence and absence of AMPK-induced insulin resistance. 


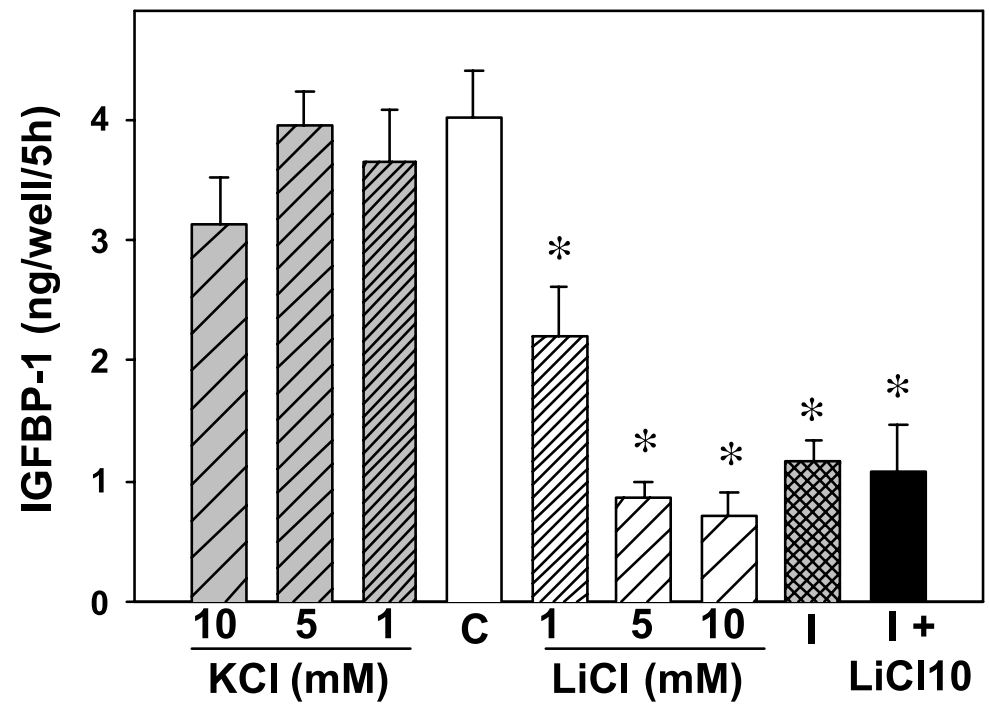

Figure 1 Lithium inhibits secretion of IGFBP-1 by H4-II-E cells. IGFBP-1 secretion was measured by immunoassay as described in the Methods. The effect of $10 \mathrm{mM} \mathrm{LiCl}$ was not additive to a maximally inhibitory concentration of insulin (I, $100 \mathrm{ng} / \mathrm{ml}$ ). Results are the mean \pm SE pooled from 3 experiments, each having 3 replicates per condition. ${ }^{*}, \mathrm{P}<0 \cdot 001$, compared to control (C).

\section{Materials and Methods}

Lithium chloride $(\mathrm{LiCl})$ and potassium chloride $(\mathrm{KCl})$ were purchased from Merck (Darmstadt, Germany) and 5-aminoimidazole-4-carboxamide-riboside (AICAR), from Sigma (Sweden). Recombinant human insulin (Actrapid) was obtained from Novo Nordisk (Denmark). H4-II-E cell maintenance and IGFBP-1 immunoassay have been described previously (Lewitt, 2001). In brief, rat IGFBP-1 was measured using an antibody capture assay. Rat IGFBP-1 was used as the fixed antigen competing for rabbit polyclonal anti-rat IGFBP-1 antibody with pure rat IGFBP-1 standard or sample. The effective assay range was 0.05 to $10 \mathrm{ng}$. At $0.9 \mathrm{ng}$ the between and within-assay imprecisions were $15 \%$ and $4 \cdot 8 \%$ respectively. Experiments were in 96-well plates (Costar, Corning, NY) using confluent cells after $24-\mathrm{h}$ serum-free. Incubations were in $200 \mu \mathrm{l}$ and, after a $1 \cdot 5-\mathrm{h}$ preincubation, medium plus effectors were replaced for a $5-\mathrm{h}$ or $16-\mathrm{h}$ collection. In experiments to determine recovery, 16-h conditioned medium was removed before two 5-h collection periods. Samples from one experiment were run in the same assay using 10-50 $\mu \mathrm{l}$ medium. Results are the mean \pm SE. Unless otherwise indicated, statistical significance, taken as $P<0 \cdot 05$, was determined by analysis of variance (SigmaStat, SPSS Science, Chicago, IL). Cell viability was measured by colorimetric assay using 3-(4,5dimethylthiazol-2-yl)-2,5,-diphenyltetrazolium bromide (MTT; Mosmann, 1983) Native PAGE was according to a published method (Jones et al., 1991). Concentrated samples containing $10 \mathrm{ng}$ IGFBP-1 from control and
$10 \mathrm{mM}$ LiCl-treated cells were run on $10 \%$ gels, transferred to nitrocellulose, incubated with anti rat IGFBP-1, B4 1:1000 (Lewitt et al., 1994), and detected with radioiodinated protein A (Sigma) and autoradiography. For studies of mRNA expression, cells were incubated in 12 -well plates (Costar) with the effectors for $2 \mathrm{~h}$ and total RNA extracted using guanidine isothiocyanate-phenolchloroform (Trizol, Life Technologies, Sweden). Northern blots were hybridized with a rIGFBP-1 cDNA probe (GenBank M89791, kindly provided by Guck T. Ooi), labelled with ${ }^{32} \mathrm{P}-\mathrm{dCTP}$ by random prime labelling (Ready-To-Go, Amersham Pharmacia Biotech, Sweden).

\section{Results}

IGFBP-1 secretion by H4-II-E cells was inhibited in a dose response fashion by $\mathrm{LiCl}$ (Figure 1). $\mathrm{KCl}$, used as another control, did not inhibit IGFBP-1. Under these culture conditions, lithium inhibited IGFBP-1 by $80 \%$, to a similar extent as a maximally effective concentration of insulin, however the effects of insulin and lithium were not additive. $\mathrm{LiCl}$ not only inhibited levels of IGFBP-1 protein secretion, but also effectively inhibited IGFBP-1 mRNA expression (Figure 2).

In order to exclude a non-specific, toxic effect of lithium we assessed the reversibility of the inhibitory effect of lithium on IGFBP-1 after a more prolonged incubation period. As shown in a representative experiment in Figure 3 , after a 16-h incubation, lithium remained an effective inhibitor of IGFBP-1, inhibiting secretion by more than 


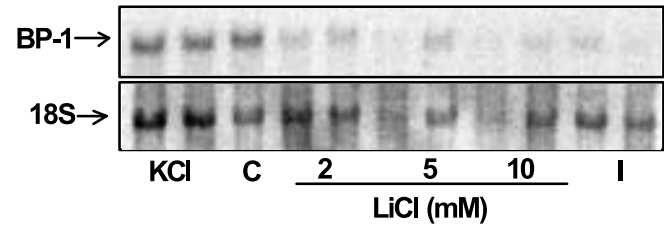

Figure 2 Inhibition of IGFBP-1 mRNA expression by $\mathrm{LiCl}$ in $\mathrm{H} 4-\mathrm{II}-\mathrm{E}$ cells. Cells were exposed to effectors for $2 \mathrm{~h}$. As controls, cells incubated without $(\mathrm{C}, \mathrm{n}=1)$ and with $\mathrm{KCl} 10 \mathrm{mM}(\mathrm{KCl}, \mathrm{n}=2)$. The effect of increasing concentrations of $\mathrm{LiCl}(\mathrm{n}=2$ for each) is compared with insulin $100 \mathrm{ng} / \mathrm{ml}(\mathrm{l}, \mathrm{n}=2)$.

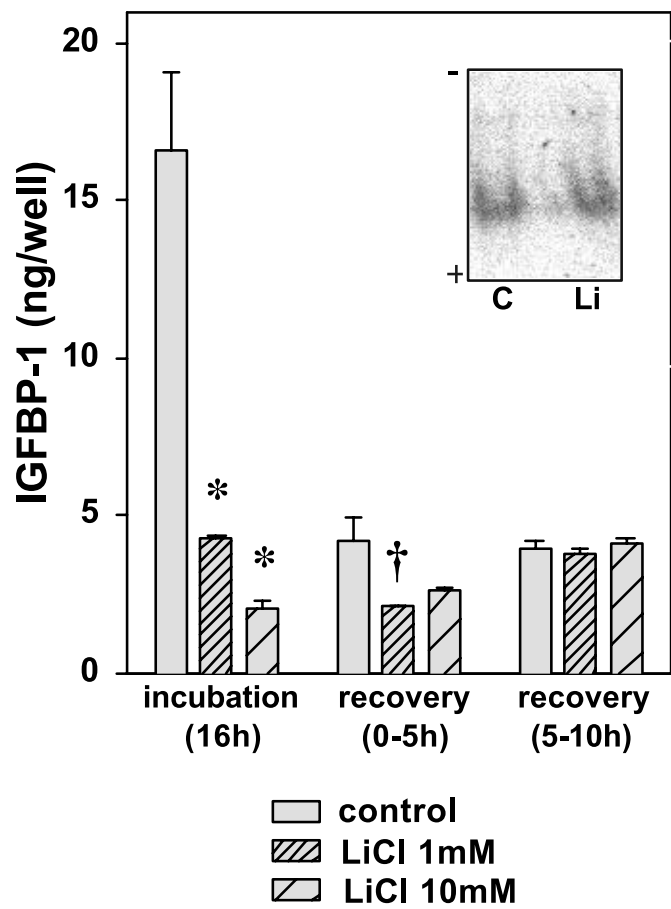

Figure 3 Recovery of IGFBP-1 secretion after long-term inhibition by $\mathrm{LiCl}$ in $\mathrm{H} 4-\mathrm{II}-\mathrm{E}$ cells. Cells were exposed to $\mathrm{LiCl}$ for a $16-\mathrm{h}$ incubation. The conditioned medium was collected and cells incubated in the absence of lithium for two $5 \mathrm{~h}$ recovery periods. Results are the mean \pm SE of 4-8 replicates per condition. *, $\mathrm{P}<0.001, \mathrm{\dagger}, \mathrm{P}<0.05$ (compared to no lithium within a given incubation period). Lithium had no effect on the pattern of secreted isoforms of IGFBP-1 (inset). Samples from control (C) and $10 \mathrm{mM} \mathrm{LiCl}(\mathrm{Li})$ treated cells, containing $10 \mathrm{ng}$ IGFBP-1 were subjected to immunoblotting after non-denaturing PAGE.

$80 \%$. This contrasts to the inhibitory effect insulin, which diminishes with time (Lewitt et al., 1996). Within hours of removal of lithium, lithium's inhibitory effect on IGFBP-1 was completely reversed. In a parallel experiment, cell viability was assessed after a $16-\mathrm{h}$ exposure to $10 \mathrm{mM}$ lithium. After a 4-h incubation with MTT, the quantity of formazan product in solubilised lithium-treated cells was $6 \cdot 0 \pm 2 \cdot 7 \%$ greater than in control wells $(n=6, P<0 \cdot 05$, $t$-test).

Lithium has an effect, albeit less potently, on protein kinases other than GSK3 (Davies et al., 2000), including casein kinase 2, which can phosphorylate IGFBP-1 (Ankrapp et al., 1996). In Figure 3(inset) we show that the pattern of isoforms of IGFBP-1 seen on immunoblotting after native PAGE are not changed by $10 \mathrm{mM}$ lithium chloride. There was also no change in intensity of the bands detected in these $10 \mathrm{ng}$ samples.

AICAR, which activates AMPK, has been shown to block the inhibitory effect of insulin of IGFBP-1 secretion in these cells (Lewitt, 2001). We determined the combined effect of lithium and insulin in the presence of AMPK activation. In the presence of AMPK activation, an inhibitory effect of lithium was observed (Figure 4). This contrasts to the finding that, in the presence of insulin without AMPK activation, lithium is unable to further inhibit IGFBP-1 secretion. The tendency to a stimulation by insulin in the presence of AMPK activation and lithium inhibition was not statistically significant.

\section{Discussion}

In this paper we present the novel observation that lithium chloride acutely and reversibly inhibits IGFBP-1 expression and secretion, without affecting its phosphorylation status. Lithium chloride is an inhibitor of GSK-3 (Davies et al., 2000), a protein kinase with a wide spectrum of action on gene transcription, protein translation and microtubule stability (Coghlan et al., 2000). The observation, in the same cell line that we have used, that GSK-3 is involved in the regulation of PEPCK and glucose-6phosphatase, leads to us to conclude that it is a likely candidate to be involved in a pathway leading to IGFBP-1 inhibition. The activator of such a pathway leading to changes in IGFBP-1 synthesis in vivo is speculative. Amino acids might play this role, since they have been shown to inhibit GSK-3 in muscle cells (Peyrollier et al., 2000; Armstrong et al., 2001) and are known to inhibit IGFBP-1 in vivo and in vitro (Pao et al., 1993; Straus et al., 1993).

IGFBP-1 expression often changes in parallels with other genes involved in glucose homeostasis. However GSK-3-dependent changes could regulate IGFBP-1 for roles other than glucoregulation. IGFBP-1 prevents apoptosis by an IGF-dependent mechanism (Butt et al., 1999), and by IGF-independent pathways, such as interaction with integrin receptors to induce FAK dephosphorylation (Perks et al., 1999). GSK-3 $\beta$ participates in cell survival pathways. Disruption of the GSK-3 $\beta$ results in hepatocyte apoptosis and embryonic lethality (Hoeflich et al., 2000). However acute inhibition of GSK3 promotes survival of primary neurones (Cross et al., 2001). Any role of IGFBP-1 in these responses is purely speculative at this time.

The observation that the combination of maximally effective concentrations of insulin and lithium were not 


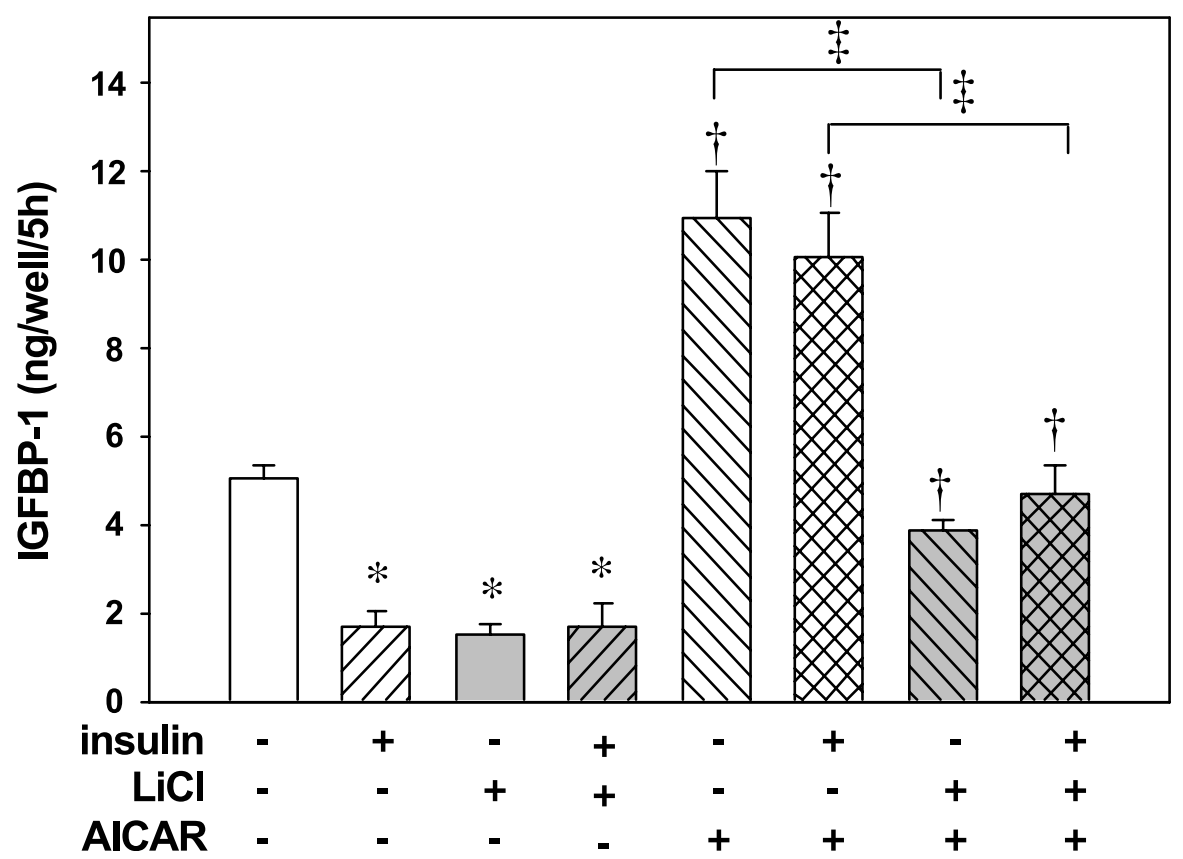

Figure 4 Lithium inhibits IGFBP-1 in the presence AICAR, which blocks the inhibitory effect of insulin. IGFBP-1 concentrations were measured by immunoassay as described in the Methods. Results are the mean \pm SE pooled from 3 experiments, each having 3 replicates per condition. ${ }^{*}$, $\mathrm{P}<0.01$ (compared to no additions); $\uparrow, \mathrm{P}<0.01$ (compared to no AICAR); $\neq, \mathrm{P}<0.001$.

additive in suppressing IGFBP-1 suggests an alternative mechanism of lithium action, involving a common pathway with insulin. It is possible that, like insulin (Cichy et al., 1998), lithium inhibits IGFBP-1 via PKB/Akt and that the inhibitory effect AMPK activation on insulin action is upstream of PKB/Akt. In support of this hypothesis, lithium has been shown to be an activator of $\mathrm{PKB} / \mathrm{Akt}$, although in another cell type, neurons (Chalecka-Franaszek \& Chuang, 1999). Another possible explanation for this phenomenon is that insulin activity itself may inhibit a lithium-activated pathway leading to IGFBP-1 inhibition.

In conclusion, we have identified a novel inhibitor IGFBP-1 production. Furthermore we report that lithium is still able to inhibit IGFBP-1 secretion when the inhibitory effect of insulin on IGFBP-1 is blocked with the AMPK-activator, AICAR. This leads us to speculate on the potential role for activating this pathway in insulin resistant states. Unravelling these pathways of action on IGFBP-1 is the focus of our current investigations.

Acknowledgements

The authors thank Inga-Lena Wivall-Helleryd for technical assistance and Professors Kerstin Hall and Suad Efendic for their helpful discussions. This research was supported by the Swedish Medical Research Council (04224), the Novo Nordisk Foundation, and the Swedish Diabetes Association.

\section{References}

Ankrapp DP, Jones JI \& Clemmons DR 1996 Characterization of insulin-like growth factor binding protein-1 kinases from human hepatoma cells. Journal of Cellular Biochemistry 60 387-399.

Armstrong JL, Bonavaud SM, Toole BJ \& Yeaman SJ 2001 Regulation of glycogen synthesis by amino acids in cultured human muscle cells. Journal of Biological Chemistry 276 952-926.

Baxter RC 2000 Insulin-like growth factor (IGF)-binding proteins: interactions with IGFs and intrinsic bioactivities. American Journal of Physiology 278 E967-E976.

Bosch F, Rodriguez-Gil JE, Hatzoglou M, Gomez-Foix AM \& Hanson RW 1992 Lithium inhibits hepatic gluconeogenesis and phosphoenolpyruvate carboxykinase gene expression. Journal of Biological Chemistry 2672888 -2893.

Butt AJ, Firth SM \& Baxter RC 1999 The IGF axis and programmed cell death. Immunology \& Cell Biology 77 256-62.

Chalecka-Franaszek E \& Chuang DM 1999 Lithium activates the serine/threonine kinase Akt-1 and suppresses glutamate-induced inhibition of Akt-1 activity in neurons. PNAS 96 8745-8750.

Cichy SB, Uddin S, Danilkovich A, Guo SD, Klippel A \& Unterman TG 1998 Protein kinase b/Akt mediates effects of insulin on hepatic insulin-like growth factor-binding protein-1 gene expression through a conserved insulin response sequence. Journal of Biological Chemistry 273 6482-6487.

Coghlan MP, Culbert AA, Cross DAE, Corcoran SL, Yates JW, Pearce NJ, Rausch OL, Murphy GL, Carter PS, Cox LR, Mills D, Brown MJ, Haigh D, Ward RW, Smith DG, Murray KJ, Reith AD \& Holder JC 2000 Selective small molecule inhibitors of glycogen synthase kinase-3 modulate glycogen metabolism and gene transcription. Chemistry \& Biology 7 793-803. 
Cotterill AM, Mendel P, Holly JMP, Timmins AG, Camachohubner C, Hughes SC, Ross R, Blum WF \& Langford RM 1996 The differential regulation of the circulating levels of the insulin-like growth factors and their binding proteins (IGFBP)1, 2 and 3 after elective abdominal surgery. Clinical Endocrinology 44 91-101.

Cross DA, Culbert AA, Chalmers KA, Facci L, Skaper SD \& Reith AD 2001 Selective small-molecular inhibitors of glycogen synthase kinase-3 activity protect primary neurones from death. Journal of Neurochemistry 77 94-102.

Davies SP, Reddy H, Caivano M \& Cohen P 2000 Specificity and mechanism of action of some commonly used protein kinase inhibitors. Biochemical Journal 351 95-105.

Hoeflich KP, Luo J, Rubie EA, Tsao M-S, Jin O \& Woodgett JR 2000 Requirement for glycogen synthase kinase- $3 \beta$ in cell survival and NF- $\mathrm{KB}$ activation. Nature 406 86-90.

Hopkins NJ, Jakeman PM, Hughes SC \& Holly JMP 1994 Changes in circulating insulin-like growth factor-binding protein-1 (IGFBP-1) during prolonged exercise: effect of carbohydrate feeding. Journal of Clinical Endocrinology \& Metabolism 79 1887-1890.

Jones JI, D'Ercole AJ, Camacho-Hubner C \& Clemmons DR 1991 Phosphorylation of insulin-like growth factor (IGF)-binding protein 1 in cell culture and in vivo: Effects on affinity for IGF-I. PNAS) $\mathbf{8 8}$ $7481-7485$

Kops GJPL, de Ruiter ND, De Vries-Smits AMM, Powell DR, Bos JL \& Bergering BMT 1999 Direct control of the Forkhead transcription factor AFX by protein kinase B. Nature 398 630-634.

Lee PDK, Giudice LC, Conover CA \& Powell DR 1997 Insulin-like growth factor binding protein-1: recent findings and new directions. Proceedings of the Society for Experimental Biology \& Medicine 216 319-357.

Lewitt MS 2001 Stimulation of IGF-Binding Protein-1 Secretion by AMP-Activated Protein Kinase Biochemical \& Biophysical Research Communications 282 1126-1131.

Lewitt MS, Saunders H, Phuyal JL \& Baxter RC 1994 Regulation of insulin-like growth factor-binding protein-1 in rat serum. Diabetes $43232-239$.

Lewitt MS, Saunders H, \& Baxter RC 1994 Interaction of insulin, glucocorticoids and protein kinase $\mathrm{C}$ in the regulation of insulin-like growth factor-binding protein-1 production by H4 IIE rat hepatoma cells. Journal of Cell Physiology 166 121-129.
Lochhead PA, Coghlan M, Rice SQJ \& Sutherland C 2001 Inhibition of GSK-3 selectively reduces glucose-6-phosphatase and phosphoenolpyruvate carboxykinase gene expression. Diabetes $\mathbf{5 0}$ 937-946.

Lochhead PA, Salt IP, Walker KS, Hardie DG \& Sutherland C 2000 5-Aminoimidazole-4-carboxamide riboside mimics the effects of insulin on the expression of the 2 key gluconeogenic genes PEPCK and glucose-6-phosphatase. Diabetes 49 896-903.

Mosmann T, 1983 Rapid Colorimeteric assay for cellular growth and survival: application to proliferation and cytotoxicity assays. Journal of Immunological Methods 65 55-63.

Pao CI, Farmer PK, Begovic S, Villafuerte BC, Wu GJ, Robertson DG \& Phillips LS 1993 Regulation of insulin-like growth factor-I (IGF-I) and IGF-binding protein 1 gene transcription by hormones and provision of amino acids in rat hepatocytes. Molecular Endocrinology 7 1561-1568.

Perks CM, Newcombe PV, Norman MR \& Holly JMP 1999 Effect of insulin-like growth factor binding protein-1 on integrin signaling and the induction of apoptosis in human breast cancer cells. Journal of Molecular Endocrinology 22 141-150.

Peyrollier K, Hajduch E, Blair AS, Hyde R \& Hundal HS 2000 L-Leucine availability regulates phosphatidylinositol 3-kinase, p70 S6 kinase and glycogen synthase kinase-3 activity in L6 muscle cells: evidence for the involvement of the mammalian target of rapamycin (mTOR) pathway in the L-leucine-induced up-regulation of System A amino acid transport. Biochemical Journal 350 361-368.

Salt IP, Connell JM \& Gould GW 2000

5-aminoimidazole-4-carboxamide ribonucleoside (AICAR) inhibits insulin-stimulated glucose transport in 3T3-L1 adipocytes. Diabetes 49 1649-1656.

Samstien B, Hoimes ML, Fan J, Frost RA, Gelato MC \& Lang CH 1996 IL-6 stimulation of insulin-like growth factor binding protein (IGFBP)-1 production. Biochemical \& Biophysical Research Communications 228 611-615.

Straus DS, Burke EJ \& Marten NW 1993 Induction of insulin-like growth factor binding protein-1 gene expression in liver of protein-restricted rats and in rat hepatoma cells limited for a single amino acid. Endocrinology 132 1090-1100. 